\title{
On Writing and Handwriting
}

\author{
Miloš Kučera
}

\begin{abstract}
Writing is often considered secondary to the spoken language, as it is only coded sound-by-sound. But other scholars have demonstrated that writing is similar to 'arithmetic': a cognitive structuring, a shift to the meta-level ('for the eye'). Handwriting (referred to here as the cursive writing in the sense of joined up handwriting, of 'écriture liée') differs from writing (in the first analysis): it has its own grammar composed of paradigmatic gestemes and tracemes and its own syntagmatic rules that connect them. In emotional terms, handwriting is designed to provide a special pleasure by its own drive (instinct, 'Trieb'). But there is also cognitive aspect to it: the rapidity and fluidity of a cursive writing could be (in professional writing, for instance) more important (at the climax of the creative process) than it being legible for all eternity. The project of the new handwriting reform for Czech schools, abolishing the liaison between letters, is shown to be a modern and technically simplified form of calligraphy.
\end{abstract}

Key words: Reading, writing, arithmetic, handwriting, graphemes, phonemes, gestemes, tracemes, liaison, professional writing, calligraphy, signature, legibility, rapidity, fluidity.

\section{Introduction}

The aim of the following paper is not to give a survey of eminent contemporary or classical studies on writing and handwriting. The working title of this short essay was initially 'Understanding writing and handwriting', but in the end, that seemed ambitious and egotistic: why should I be so privileged as to understand the topic? But on the other hand, I am quite sure that this field often labours under an elementary misunderstanding, even by specialists whose labour has produced 'positive' results albeit patchily. (An area that has not received due analysis is the project to introduce a new handwriting norm in Czech schools.)

I would like to introduce some concepts of writing and handwriting, without citing reeds of empiric data. This overview, based on our common (Western) and very general, 'anthropological' experience, could be called 
phenomenological (in a very broad sense of the word). Its 'anthropology' has been inspired by psychoanalysis (by the use of its drive theory in the analysis of handwriting).

\section{The 'systems' in literacy}

Czech and probably all European school children learn the 'three Rs' or trivium of reading, writing and arithmetic.

These skills involve some of the following elements of the body, which combine to form systems: the mind (the meaning of an utterance), the ear and mouth (when you hear it pronounced, read or said to be written down or when you read it more or less aloud), the eye (when you read, comprehend and transmit it to the mind) and the hand (when you write with signs in a code).

This may be a truism, but I hope to show that once we forget this truism we quickly encounter difficulties and are unable to understand different graphic activities in their specific features.

\section{The graphic raison: from space to surface}

From longitudinal research carried out by the Prague Group for School Ethnography between 1992 and 2002 [Pražská skupina školní etnografie 2005], we learn that children are not only taught literacy itself, but the broader graphic raison ${ }^{1}$ (or civilization). Let us mention some of its concepts.

Pupils, their teacher and the classroom door all display a ribbon of the same color (so that they can instantly be recognized as belonging together); the geometry of the great school building has to be described or drawn so that pupils may orient themselves; the classroom and the desks are arranged such that they represent the lines and columns of a text; the pupils are laying out the various tools of the classroom on the desk so that they can find them easily; the sheet of paper is aligned with the blackboard (which represents the same page in a perpendicular position - there is neither a cross projection, nor a mirror reflection); on they page, 'left' may mean 'facing the window' and 'right' 'towards the door' of the classroom; 'before' ('So, children, before, in the previous lesson, we worked on ...') means in terms of the text 'on the left side' or 'above' or 'on the previous page' (and 'after' means the symmetrical opposite); when searching for an element in the text, you have to go through it systematically line by line and column by column, marking off the exam-

1 La raison graphique is the French title of the translation of a book by Jack Goody, originally The Domestication of the Savage Mind. 
ples that have already been studied; on the page itself you have to distinguish what a blank space signifies: it may represent the end of a line (the paragraph), but also the space in which your answer to the question should be written (in a worksheet).

I have deliberately chosen some concepts not generally considered to be part of reading, writing and arithmetic as such. But it is even more the case that these examples, on the edges of the concept of literacy as commonly understood, demonstrate that a special form of space has been constructed: that of a sheet of paper, of a surface that is purely two dimensional (a bound book clearly has depth, but only via the act of turning the pages over, not by making holes in it as you would a block of wood). The paper's delicate surface is destined for abstract, symbolic (not real) objects ('representations'). But in receiving them, the paper is robust, almost everything is possible and nothing can go wrong. We may, for instance, group objects together however we like. This is evidently not an opinion shared by the informant in Lurija's [1976: 82] famous investigation in the Caucasus region after the October revolution. The illiterate man protested: 'You can not put the hammer and the saw together, the second will blunt the first.' (On paper we are allowed to put objects together, but not to put them on top of each other, 'through' the other: they would become indecipherable, illegible.)

This is the cognitive aspect of the problem. Let us add the problem of identity in the form of a satirical but revealing family story. A boy of about three or four takes a screwdriver and runs and digs a hole in a chair vacated by his mother, who has gone to work; at school, the same boy, now six years old, writes the word MUM slowly, on a line, from left to right: His love has to be articulated via writing. To end the story in humorous vein: the boy himself also goes on to become a member of our sedentary tribe, fat and myopic.

Reading and writing is the second major 'anthropological' decision a child makes concerning language (the first is the decision to speak ${ }^{2}$ ). In my experience, if a child has no desire to read and write, there must be a psychosexual (identity and relational) problem in terms of development.

\section{The underestimation of writing}

We have just 'constructed' the surface of paper, in terms of the acts of writing. Writing more specifically means setting down a basic code, consisting of marks. These marks very often serve as so-called graphemes encoding the

2 The third turning point could be the games played with words, the joking about with language that children do during puberty - mainly by conferring very improbable sexual meanings to neutral utterances. 
phonemes of spoken language, of speech. (The extent to which phonemes correspond to their graphemes is in some cases more than approximate, but let us leave that issue for the moment.)

This fact, empirically correct and manifest, when not correctly specified, leads to a misconception. Say we were to stick writing and reading together. The consequence would be that the 'arithmetic'3 belonging to writing is omitted. Writing, alone, without its specific power obtained through the arithmetic, is then completely subordinate to reading, to the pronunciation of that which is read, to speaking and to the spoken language as such. In this way, the concept of writing is reduced in terms of its cognitive possibilities.

The following Czech example is illustrative. Many generations of teachers and pupils have used the book Stručná mluvnice česká by Havránek and Jedlička [1981]. The book itself is excellent, but the authors' belief that they are explaining the rules used by the Czech-speaking public is less unequivocal: it is perhaps more a handbook of written or written-like language and its orthography. The whole case becomes more suggestive when we turn to the Czech title. 'Stručná mluvnice česká' means 'A Concise Czech Grammar' (grammar refers etymologically to writing). But etymologically the key word mluvnice means 'book about speaking'. And, by contrast, the official, standard spoken language is referred to as spisovny - which means literary, more precisely 'intended-to-be-written'. So, even the terminology, historically used in this field, expresses a lot of hesitation.

\section{Writing developments: towards arithmetic}

On the other side we find a colleague of Havránek and Jedlička, the Anglicist and general linguist Josef Vachek, who dedicated his work to defending the specificities of writing. I shall refer only to his texts published in English [1973, 1989]. Vachek believes that the relation between phoneme and grapheme is not one of reference, but of correspondence. All attempts to introduce spelling reforms in English have failed because they did not respect the fact the written word expresses its morphological root: right - rite wright - write are pronounced identically, but they mean different things [1973: 23]. We might say of this homonymy that the written word may be considered as having the status of the sentence in spoken language [1973: 33].

3 In this paper by 'arithmetic' I do not necessarily mean working with figures, but more generally, meta-operations. 
This clearly illustates Vachek's notion of a shift to a higher level, achieved by writing.

In his second English book Vachek [1989] scrutinizes (amongst other things) the potential 'primacy of writing', as referred to a book by Fred H. Householder. According to Vachek, even in spoken language there exist some privileged contexts in which speech expresses the traits of writing, in terms of pronunciation, for instance, in the context of singing, lento (vs. allegro) tempo, the cult and so on. In some way, all this reminds us of the 'spisovný' aspect of Czech language. But we shall not pursue this line of thought here: it would be necessary to distinguish and to maintain as mutually independent the written and oral aspects versus the written and oral text, form. This is possible, but not easy, because we would then have to do an abstraction from the direct corporeal involvement and to search in the sound of the language an element that could be a substitution for the sight, for its rapidity or its ability to grasp all at one glance, etc.

This point is also the most important conclusion we can draw from our journey to orthography: the written form 'speaks quickly and distinctly to the eyes', as Vachek puts it [1973: 19] citing another Czech linguist, Frinta: to the eyes, not to the ears.

Josef Vachek has exercised a strong influence on anthropologists interested in literacy, such as the British scholar Jack Goody. Goody [1979] stresses the importance of 'arithmetic' forms of writing such as lists and tables, which evidently lie outside the grapheme/phoneme context; in doing so he accentuates the specific role of writing in the formation of a new raison or mind.

Let us have a look at this example of a real school exercise. You write MARIE (in Czech) on the board, and then submit it to the following analysis:

$\mathrm{M} / \mathrm{A} / \mathrm{R} / \mathrm{I} / \mathrm{E} \quad$ correct Czech pronunciation according to IPA symbols /marije/ $\mathrm{O} / \mathrm{X} / / \mathrm{O} / \mathrm{X} / / \mathrm{O} / \mathrm{X}$ the graphic transformation of the word as pronounced

The use of this technique should enable pupils to see more clearly the syllabic structure of words, to distinguish the consonants from the vowels, and establish the orthographic difference. As in Goody's work, a new code, reduced to the symbols $(\mathrm{O}, \mathrm{X})$ and placed into a table with columns $(/, / /)$ is used at a meta-level to allow a better understanding of the first coding graphemes/phonemes. (Later, following E. Ferreiro's example, we will show that even this first coding initially operates with a reduced, arithmetic structure.)

We could quote a multitude of other scholars (for example the French historians of education Jean Hébrard and Anne-Marie Chartier), but we have 
chosen someone outside the field, the psychoanalyst Jacques Lacan. His insights are only partly relevant, but nevertheless stimulating.

In his seminar 'Encore' of 1972-73 [1975: 64], Lacan suggests that writing can be symbolized by the image of 'le ravinement' (furrowing), which refers to the effect the streams make as you look down from an airplane to Siberia lying below [1975:109]: you read the way they structure the two dimensions of the surface (you see it like a map) through watersheds as an exact profile of the landscape, in depth (the landscape in this metaphor could represent the ordinary spoken language).

In his seminar 'L'identification' from 1961-62 [unpublished] Lacan was already stressing the independent existence of a code of marks and its arithmetic power. Firstly, he pointed to the single stroke or notch a pre-historic hunter made each time he killed a beast: / / /, three. This sign resembles the school grade 1 or a number 1 .

Secondly, he proposed an original theory of writing based upon proper names. He argued that the ancient nations exchanged different (mutually distinguishable from one another) marks or signs of authorship or property (for instance, on recipes by different potters), and only then was this code used for the segmentation of spoken words. Both in this process and also in the modern deciphering of ancient scriptures, proper names had an enormous role to play. 'Cleopatra' in effect remains the same throughout all the languages. Thus, right from the beginning, the written form represented a general structure, one that was independent and without meaning (Mr. Wine smells no wine).

The Piagetian scholar Emilia Ferreiro [see for instance 2000] has studied the psychogenesis of literacy. Thanks to her investigations, it became obvious that both the quantity (the number of marks used) and the quality (their differentiation from one another) are important, but, in a sense, quantity dominates. At the very beginning, the image of an object was distinguished from its representation by means of letters: e. g., a 'lion' could be expressed by OXXOO, without its head or mane. The image-like concept nevertheless persisted for some time: a 'butterfly' would be rendered, say, only by the marks OXO, because in its referential reality it is a smaller animal than a lion. It is only gradually that the groups and series of marks (sometimes quite identical in quality) began to represent not the size of the object, but the length of the word or the utterance, passing thus from the logographic or pre-syllabic phase to the syllabic and then to the alphabetic, directed towards the sound without the meaning, not the concept.

The debate on the ontogenetic potential of proper names has yet to come to a conclusion: there is general agreement that they have a specific power, but nobody knows if it is for good or for bad. Some say familiarity with its letters 
could create a break-through onto the phonological plane; others stress that the signature (the representation of a proper name on paper) signifies the specific heraldic sign of the person, of her relatives and friends, rather than it having a necessary connection to other texts in their graphemic form, and that the signature is somehow over-motivated or 'over-heated' for it to be good material to be submitted to a cool phonemic analysis.

\section{Professional writing}

Let us turn now from the pupils to the professionals. Perhaps we will come across other facets of writing in their work. There is an interesting method for studying professional writing called genetic criticism [Alamargot, Lebrave 2010]. ${ }^{4}$ According to the authors, genetic criticism means 'a linguistic-literary discipline that reconstructs the genesis of an author's manuscript by collecting and interpreting the notes, drafts, revisions, successive versions, etc.'

In their paper, these scholars include a beautiful second draft of the incipit of Herodias by Flaubert (unfortunately, it is greatly reduced and practically illegible; but, perhaps, the original is not much better: see later the remark about the size and text quantity) (Fig. 1).

They describe it thus: 'Alongside the host of rewritings (crossings-out, substitutions, additions), this sheet contains a diagram in the margin, which the author used to solve a textualization problem (notably the shape of the mountain on which the fortress was built), and lines linking passages together, thus, making it easier to reread the text amidst the tangle of selected or rejected fragments'.

But these remarks are all there is to it, there is no other analysis of this fascinating re-print. Nor is there anything else on the problem of professional writing as writing.

The authors introduce two pairs of opposing concepts that so indirectly contain the writing that we could suppose professionals write only purely mentally, without the aid of marks on paper.

The first opposition is between the classical and romantic methods of writing. The classical method consists of 'drafting a plan beforehand', the romantic of 'alternating phases where thoughts are freely expressed in a continuous writing flow (ignoring the quality of textual organization) and phases in which the resulting text is critically assessed and revised.'

I do not reject this distinction, but perhaps it would be of some use to stress the common root, introduced by writing. I suppose that in both cases

4 Denis Alamargot was extremely kind and sent me a digital pre-print of his paper. 


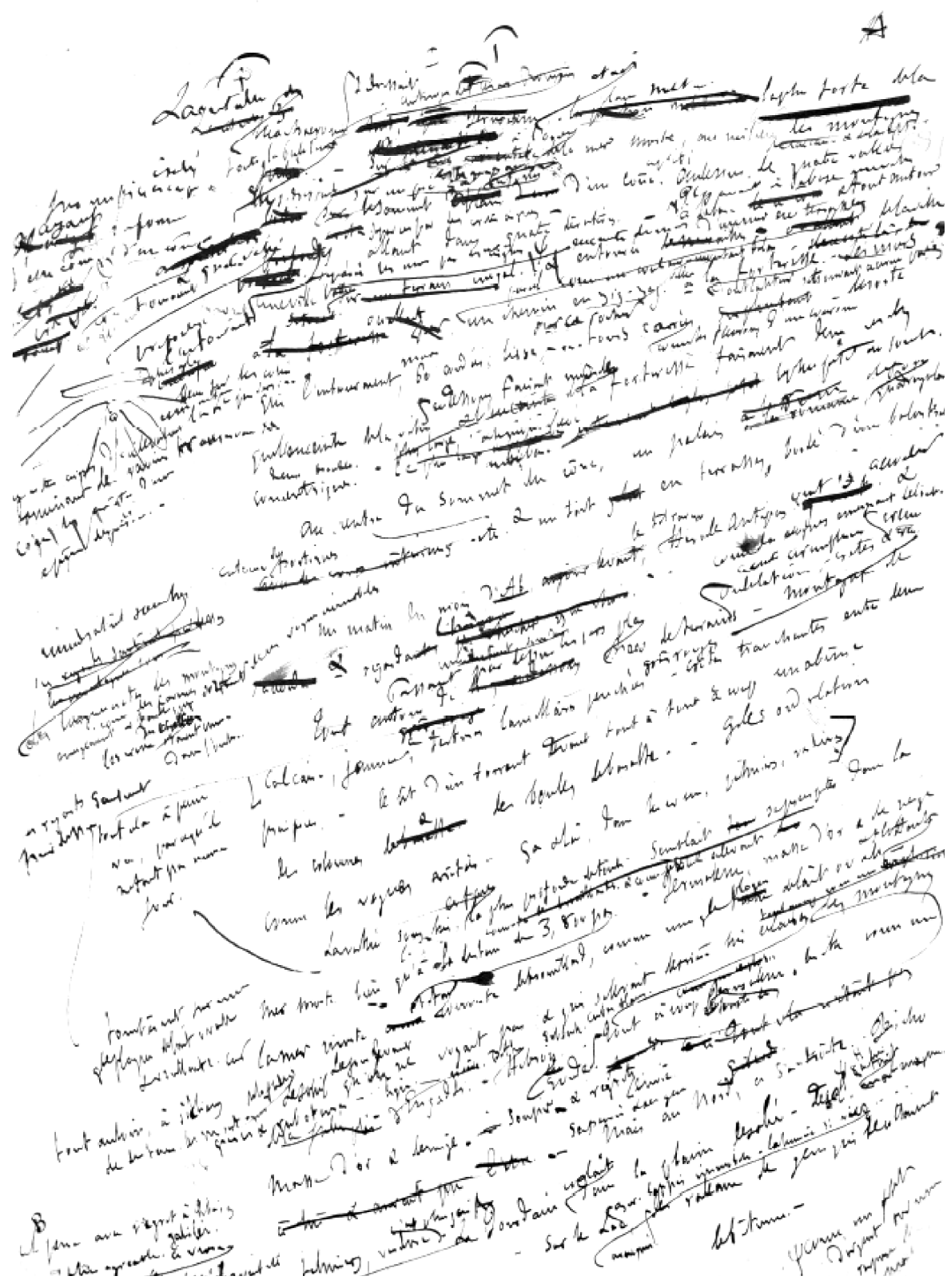

Fig. 1. Source: Alamargot, Lebrave

it is a procedure by which the unconscious mind is loaded with a task which is then solved during an interval, a break after which inspiration then comes. In the first example, associations are probably made in a metonymical direction (the specification of general ideas), in the second, perhaps they go in the direction of further metaphors which would afterward be generalized in the 
plan (of latent ideas) (?). (In a sense, according to Lacan, the unconscious is organized in written form, too, and there is an interaction between this 'new' task and the old, persistent structures.) In both cases it would be the writing (at one time by means of a written plan, at the other time by the written text itself, transmitting its structure to the following text) that makes a coherent text possible.

The second pair of concepts constitutes the memory of the process (of writing) versus the memory of the content (of writing). The first memory contains meta-notes on what not to forget, what is to be done next time and so on, and the second comprises references to the plot, e. g. What seems to be the point? Look at the incipit by Flaubert: it resembles a cognitive map, or, in this case, an emotional and cognitive map, with pieces of finished texts (see the romantic method). Perhaps it was in the fever of creation that he rapidly added notes, sketches and so on in the form of suggestions and shorthands, in 'anticipation' on a single sheet: before his ideas could disappear (and even these perhaps would, after a long period, disappear or become illegible as is the experience of scholars and scientists, when we return after months or years to our old data and the whole 'world' they create).

My aim was not to criticize this excellent study, but to show that writing is always linked to information that can be rapidly and 'globally' received through the eye. When we, professional theorists, write a text, we prefer, very often, to work with as small a script as possible, thus capturing the maximum of text on one sheet, at a glance, as Flaubert did. Viewed from another perspective: there is no text without a special medium, and in order to construct this text we require an entire system with memory in the mind, memory on paper, anticipation in the mind, anticipation on paper, but it also requires the eye, and as we shall see, the hand, all working together. In my opinion, a description of writing cannot focus simply on the cognitive side, without considering the medium, the physical 'bearer' (which is so much more than a bearer).

\section{Handwriting trends: away from the arithmetic}

After this apologetic account of writing as a cognitive and 'arithmetic' tool, the heading of the paragraph seems quite surprising. In terms of one of its aspects, handwriting is completely different from writing as such. (Later, we will replace this title with another, in which handwriting will stand for the return of arithmetic, in a special way.)

Hypothetically, Flaubert could have produced his incipit by computer (of course, the slowness of this instrument and its built-in standards of com- 
pleteness and correctness would probably block the creative process, hide earlier suggestions and so on). In all our demonstrations of writing we have yet to mention the simple fact that writing has to be done in a physical manner, very often with the hand (holding a pen or a pencil) on paper.

Anybody can carry out the following experiment: choose a word, shut your eyes and write it down. You will probably be very successful and the result will be legible. This example makes it clear that there may be a special skill with a special 'grammar' at work. But first, we have to indicate the kind of handwriting we will deal with now.

\section{Cursive (joined up) handwriting}

Here we have in mind the 'handwritten Latin' (psaci latinka) which was adopted in Czech schools in 1932 [Penc 1968: 23] and still remains (with some changes) the norm, the model, the script. It probably represents an interesting historical and anthropologic construction or invention which is not used in all schools across the world. The crucial criterion of this script is, in my opinion, that a word should be accomplished in a single movement, in one gesture, without interruption. This handwriting is referred to as "cursive/joined up handwriting', or in Czech as 'vázané písmo', and in French as 'écriture liée'. It is clear that this fact of liaison contains also an important amount of rhythmicity. (Incidentally, in the history of handwriting there is a method where the rhythm was dictated by the teacher counting out one, two, three; its author was Audoyer [in Penc 1968: 64]).

Let us also remind ourselves of the fact that children invent or imitate different forms in their proto-writing. We find them making those series or groups of single, isolated marks that Ferreiro mentions, but they also like drawing uninterrupted curves and waves from one side of the page to the other (not unlike this computer simulation):

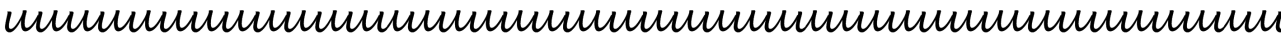

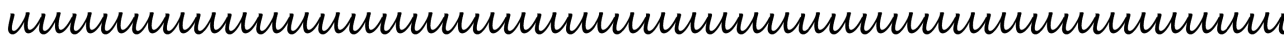

But it is really only a form of proto-writing. When they go to school, some children can read or even write in capitals or even little block letters, but no one can boast of a joined up writing. Considerable practice is required both at school and home. Obviously, over time, teachers have become considerably less demanding in requiring a single gesture (e. g., pupils are now allowed to pause in order to add a diacritic mark, and only then continue). The 
criteria regarding the slant and speed of handwriting have been relaxed and fewer practice sessions are timetabled. ${ }^{5}$

\section{The Grammar of Handwriting}

In considering joined up handwriting, I shall introduce (as neologisms), in analogy to the phoneme and grapheme, two other '-emes': gestemes and tracemes. We can observe them clearly in this table, which Penc [1968: 25] entitles 'Shapes of letters and numbers'
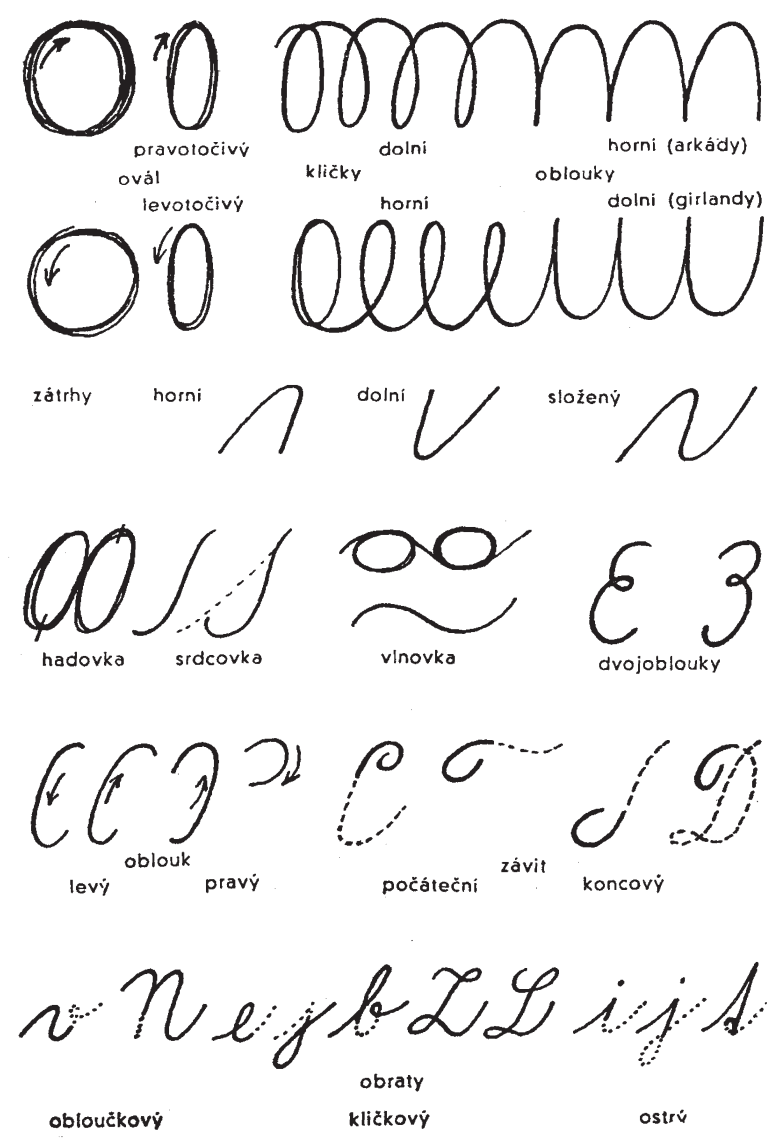

Fig. 2. Source: Penc 1968

5 It is rather curious to argue in the current debate that nobody 'fully' produces this script (as if it were a rarity inherent in the script), when in fact pupils are not 'fully', or sufficiently taught it. Following this argument we would have to give up singing and other arts and skills. 
Tracemes are the traces of the hand movement: not only what a letter is, but also what it looks 'like', what the 'ideal' shape tends to be. Gestemes are represented in figure 2 by shapes where a multiple line expresses repetition: the repetition which in fact occurs during preparatory and warm-up exercises (some of them are simply made in the air, without touching the paper).

A story that illustrates this goes as follows: a pupil tells the teacher that his mother advised him to write the letter ' $m$ ' in such a way so as not to repeat the same movement from bottom (from the baseline) to top, but to connect the three 'mountains' one after the other just above - it would be more beautiful. But the teacher insists on the gesteme and traceme, even though the grapheme remains approximately the same. In Penc's figure, too, we can see - demonstrated by the additional dotted lines - syntagmatic rules for the connection of tracemes. Admittedly, when we examine some adults' handwriting we find that the syntagmas of the gestemes often integrate the diacritic marks and sometimes represent a unit greater than a word (in this case the segmentation into words is carried out so that the line does not touch the paper for even a moment: but the continuation of the gesture is evident).

So, we find that there is an interesting shift not only in terms of 'normal' writing (re:Vachek), but also in terms of the handwriting. We could even say that cursive handwriting represents 'global' writing (as if speaking about 'global reading'): where it seems as if the idea had already been read as a word in the mind, and so was put down on the paper (see later for a return of the arithmetic). This could be the reason handwriting is sometimes used as a remedial technique for dyslexia [Fernald 1943].

\section{A sublimation and a new drive}

When pupils are eventually well practiced at handwriting, they experience a functional pleasure in accomplishing the act of writing. The notion of 'pleasure' takes us into the realm of drive theory. Will the handwriting represent a pure drive, or rather a sublimation? It does not matter much, and I introduce this dilemma simply in the interests of comparison. If it is possible to find a rougher, more primitive version of an activity (its de-sublimation), the activity in question could be called a sublimation of it. Let us take for instance finger painting as used in art therapy. It is indicative of the anal stage in drive theory, it is a 'regression', a de-sublimation. On the other hand, its connection to the eye and to scopic drive remains; but this has always been there, from the very beginning (as is the case with toilet paper for example).

Many sublimations can be found in terms of handwriting. The writer just has to remain on the surface (sublimation), not dig deep, not make a hole 
(drive or de-sublimation, a rough version); to go lightly (sublimation), not have a scratching fit (drive); to proceed quickly (sublimation), not stop and make a blot which would be like urinating in bed (drive); to continue only with the pen (sublimation), not involve the whole body (drive); to grasp the beloved object simply with the thought in the form of a line (sublimation), not blindly with the arms (drive) ... ${ }^{6}$

But we can also maintain that handwriting, this sublimation, contains all the drive components outlined in Freud's concept ${ }^{7}$ : the source is corporeal, located in the hand which is innervated, the rest of the body being disconnected and relaxed; this zone represents a new, specific motoric channel for the discharge of energy - that is the aim. But what about the object? The object of this drive could be an idea to-be-expressed, but only by the line, by the ink trace of gesture on the paper (see above). So is it the line? There is interaction: the idea to-be-expressed is repressing the attention given to the line, to the means of its own expression. Since the focus is on the content, the form is free, and can be filled with any 'unconscious' projections. This is the 'raison d'ętre' of graphology (how speculative it can be).

Let us clarify the specificities of handwriting by another comparison. We have already mentioned finger painting. But handwriting also differs from calligraphy. Beautiful Western handwriting is accomplished like a drawing and sometimes even resembles painting - in the sense that the end product does not always allow us to detect how the 'trace' was or should be carried out. Eastern calligraphy resembles joined up writing far more because of the importance of the gesture. In both calligraphies, attention is focused on the form (for the eye). In Eastern calligraphy there is (in addition) a constant interaction between the gesteme and the traceme, the second exhibiting the first as clearly as possible, the gesteme being otherwise invisible (the spectator not having been there, during execution).

This model of Eastern calligraphy is, in a way, close to the modern tags sprayed by adolescent males on city walls. The tag represents a signature. In normal handwriting, the signature (i. e., the writing of a person's name) is also a special case, designed more than other texts to appeal to the eye and bearing a special projective meaning (see also the remark above about its over-motivation). Not one that is deeper, but that is closer to a manifestation

6 There is a children's game which de-sublimates handwriting, called 'Hamster's Post'. The player 'writes' (without a pencil) on the back of another virtual letter: 'Dear Grandma, I am sending you a hamster! (the exclamation mark is replaced by a blow) The hamster scratches, bites and pinches (all simulated with the hand).

7 For the components of a drive, see Freud 1957: 122-123 or Laplanche, Pontalis 1967, headword "Pulsion". 
of the ego. Signatures tend to include paraphs. The paraph was originally a flourish that followed a legible signature as a precaution against forgery (thus, a signature with a paraph says: 'Only I have embellished this paper!').

These examples of Eastern calligraphy, tags and signatures, so dear to the heart of their authors, underline the liaison of the gesture which is perhaps a condition of pleasure: one should not be interrupted in the midst of the act.

So, handwriting is a pretty little drive to have at our disposition. As a society, we can choose not to use it. But in doing so we should know what we are doing. We should understand the concept.

But let us now turn from pleasure to cognition.

\section{With a simplified calligraphy to a simplified cognition?}

The new handwriting script that is, perhaps, to become the new national standard in Czech schools is the Comenia Script, was created by a graphic designer, Radana Lencová. The author explained the principles behind her work and her motives in several newspaper debates. ${ }^{8}$

This new script goes against the liaison between letters mentioned above. R. Lencová argues that in the existing handwriting script the shape of the letters is hidden in the 'loops and waves' that connect them.

Let us have a look at what she means.

$$
\begin{aligned}
& \text { otviraim knihu a je mi milá, } \\
& \text { maminka ju pro me vytvorila } \\
& \text { a tata rád ji pomáhal, } \\
& \text { kdyz mésic na nebi panoval. } \\
& \text { ted' Slunce vyslo, sviti, za'ri, } \\
& \text { já súsmévem na svoji tvári } \\
& \text { čtu kaídé slovo, każdou vètu } \\
& \text { a otvirám své srdce svétu. }
\end{aligned}
$$

Fig. 3. Source: home page of R. Lencová.

This is a little poem written in the new script.

The letters are clearly separated, the distance between the words is slightly greater.

8 Cf. these internet articles: iDnes, 20 april 2010, "Konec psacího písma? Školy mohou přestat učit krasopis" ("The end of handwriting? Schools may stop teaching calligraphy' - the title of the article by journalist R. Wallerová indicates her confused understanding of the two concepts: in my opinion, it is rather that the new script invokes calligraphy in its 'technical' form); Novinky.cz, 5 July 2010 'Někteři prvñáčci začnou od záři psát novým písmem' (From September, some first-graders will begin writing with a new handwriting script - no author). 


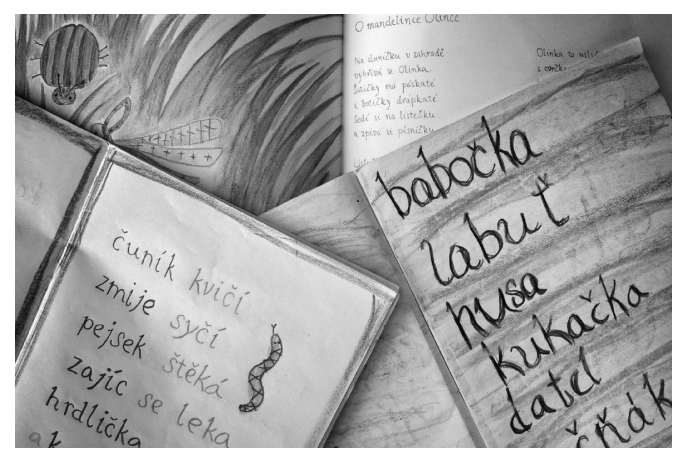

Fig. 4. Source: iDnes.cz. These probably constitute some of the preparatory and practice exercises for the new script,

on the right side of the figure (the form of letter is repeated).
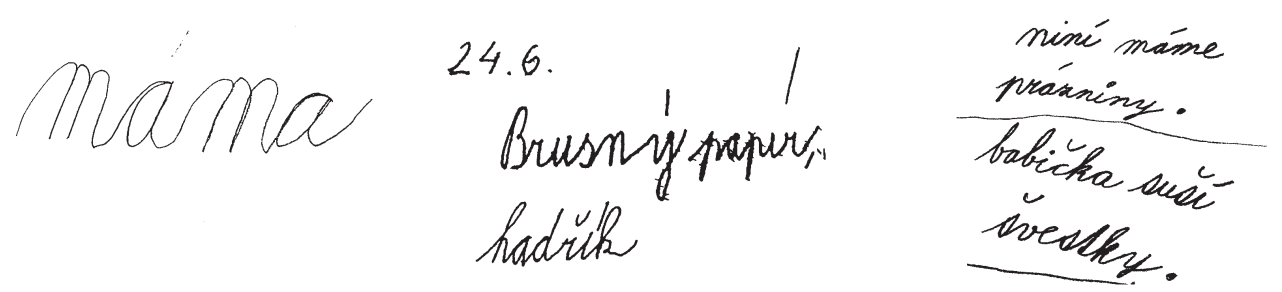

Fig. 5. Source: Prague Group for School Ethnography. For comparison, here are two texts from October and June of the first school year, and one, the last one, from the second year (the orthographic errors are due to the fact it was a difficult spelling dictation and not a copying exercise). The letters are joined, which is perhaps not so easily achieved during the first year, but in the third example from the second year we can admire the work of a very relaxed and 'happy' writer.

The letters stand alone therefore in my terminology I consider them to be drawn rather than written. R. Lencová argues that every letter made by hand is a written letter. This proves that for her the manner in which it is achieved, the gesteme, is irrelevant, only the final image is of importance.

In the debate over the new handwriting script the Czech Chamber of Graphology which protested against the end of letters liaison: it would lead to the loss of self-expression. Of course, profession graphologists need liaison as an important marker of individuality. But besides the pragmatic motivation, the statement contains much that is true. Why do I think so?

One of the arguments used by R. Lencová is that students and adults tend to neglect or discard the old script in their later school and professional careers. But it is not certain that the liaison between letters is entirely neglected, beyond some forms (for example, the replacing of cursive with block capitals at the beginning of sentences). Sometimes, breaks appear making it 
less connected but sometimes it is transformed into new syntagmas, very creatively. Could this also be achieved with the Comenia Script? And is the new script then more liberal? (Another value mentioned during the debate.)

The second point refers to R. Lencová's assertion that written communication should become simpler, and she points to the existence of the computer, e-mail, SMS and so on. 'People often complain that their own handwriting and that of their children is not legible' [Lencová in Wallerová 2010: 3]. But the legibility of a script is a rather narrow aspect of the whole cognitive theme.

\section{Legibility versus fluidity: the return of arithmetic}

Penc [1968: 6] admits that the model, the norm is transformed into an 'individualized handwriting', which should nevertheless incorporate such general qualities as legibility, neatness and agility [1968: 33]. Let us de-construct the last one. Agility clearly refers to rapidity, but perhaps also to fluidity .

Fluidity causes rapidity, but also has a quality of its own. The writer should not be forced to stop the flow of writing ahead of time as it is only then that the act of writing will not disturb his concentration on the idea to-be-expressed. There should exist, at least, the liaison at the level of gestemes, when not at the level of tracemes and graphemes. R. Lencová based her decision on the criterion that isolated letters be legible for every person and at every time, but what about fluidity? In the Comenia Script, the single movement is continually being interrupted, and I am afraid to say that the writer has to go back in order to form some of the letters: see the 'd' and ' $y$ '.

Rapidity and fluidity are also important cognitive qualities of a handwriting model. Let us return to the creative process of professional writing (above). Sometimes, we write very slowly, ruminating over the written word (waiting for inspiration), and repeating it aloud ... But suddenly, the idea appears through the mist, we have 'counted' the result in our mind (we do not know yet, how), and we need to write it down even in a provisory form, as quickly as possible, before it returns to the shadows.

\section{In conclusion}

Instead of writing a résumé (for this, see the Abstract) I will try to create an itinerary of our journey from concept to concept, or at least of its main route, without the many digressions.

(1) reading and writing involve the broader graphic mind or raison, whereby a two-dimensional world, the surface, is created; (2) writing should 
not simply be understood in the context of the coding of phonemes by graphemes: it represents a shift on the meta-level, a sort of arithmetic; (3) primarily, this arithmetic constitutes the revealing of a structure; (4) this is the cognitive side, but we must bear in mind that it is made possible by the fact that writing reveals a structure for the eye, readable at one glance (see the remarks on Alamargot and Lebrave); (5) but surprisingly, handwriting appears as a negation of ordinary cognition (the idea is expressed in the distinct 'grammar' of the gesture and its line of tracemes) and even a negation of the eye: everything focuses on the hand and its emotion, the drive and its pleasure; (6) the new Czech school handwriting reform project ignores this drive, as it is focused on the final image of a letter, not on it being created by an uninterrupted gesture; (7) the purpose of this new script should be its continued legibility to all; (8) but that is a rather narrow conception of the cognitive function of writing: e.g., fluidity (which seems to be only an emotional aspect) re-introduces cognition: e.g., when the reader was required to write something down quickly, without disturbance, under inspiration, an idea coming to birth (it does not have to be 'entirely' legible).

\section{References}

Alamargot, D., Lebrave, J.-L. 2010. The Study of Professional Writing. A Joint Contribution from Cognitive Psychology and Genetic Criticism. In European Psychologist, 15 (1): $12-22$.

Fernald, G. M. 1943. Remedial Techniques in Basic School Subjects. New York: McGraw Hill.

Ferreiro, E. 2000. L' écriture avant la lettre. Paris: Hachette.

Freud, S. 1957. Instincts and their Vicissitudes. In The Standard Edition of the Complete Psychological Works of Sigmund Freud. Volume XIV (1914 - 1916), London: The Hogarth Press, 11 - 140.

Goody, J. 1979. La raison graphique. Paris: Minuit.

Havránek, B., Jedlička, A. 1981. Stručná mluvnice česká. Praha: Stát. pedag. nakl.

Lacan, J. 1975. Encore. Le séminaire 1972 - 1973. Paris: Seuil.

Lacan, J. L'identification. Le séminaire 1961 - 1962. (Officially unpublished, accessed 14 July 2010 from http.gaogoa.free.fr)

Laplanche, J., Pontalis, J. B. 1967. Vocabulaire de la psychanalyse. Paris: Presses Universitaires de France.

Lurija, A. R. 1976. O historickém vývoji poznávacích procesů. Praha: Academia.

Penc, V. 1968. Metodika psaní. Praha: Stát. pedag. nakl.

Pražská skupina školní etnografie. 2005. Psychický vývoj ditěte od 1. do 5. třídy. Praha: Karolinum.

Vachek, J. 1973. Written Language. General Problems and Problems of English. The Hague: Mouton. 
Vachek, J. 1989. The Written Language Revisited. Amsterdam: Benjamins.

Wallerová, R. 2010. Konec psacího písma? Školy mohou přestat učit krasopis. In iDnes, 20 april 2010 (accessed 23 april 2010 from http.zpravy.idnes.cz)

For the Comenia Script see the homepage of Radana Lencová: www.lencova.eu/cs/ gal_ukazky_cs (accessed 14 July 2010).

\section{Author}

Miloš Kučera, Ph.D., Associate Professor

Charles University

Faculty of Education

Department of Psychology

M. D. Rettigové 4

11639 Praha 1

Czech Republic

E-mail: milos.kucera@pedf.cuni.cz 